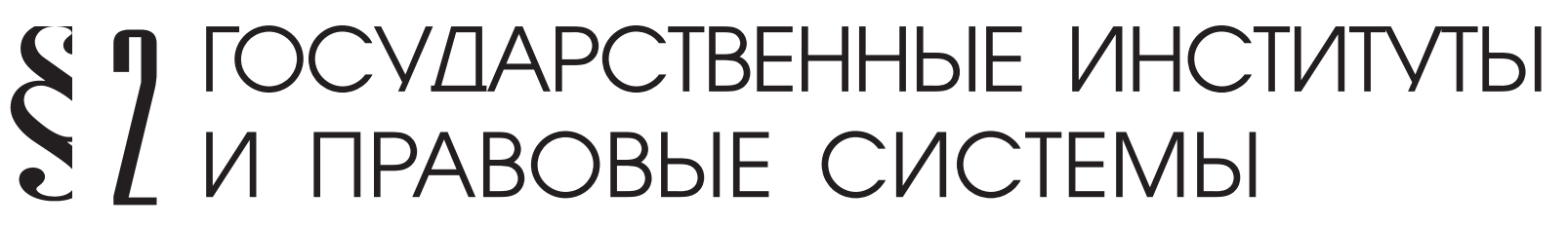

Кравец И.А

\section{РОССИЙСКИЙ РЕСПУБЛИКАНИЗМ И ПРОБЛЕМА РАЗДЕЛЕНИЯ ВЛАСТЕЙ}

\begin{abstract}
Аннотация: В статье автор исследует проблему идентификации российского республиканизма и конституционализма, показывает взаимосвязь между конституционными формами правления $u$ моделями разделения властей, раскрывает научные подходы к пониманию природы и особенностей республиканской формы правления, установленной Конституцией РФ 1993 года. Особое внимание в работе уделяется динамическим возможностям, реалиям и перспективам развития республиканской формы правления в России. В исследовании анализируются теоретические основы, истоки принципа разделения властей, конституиионные контуры моделей разделения властей («гибкая», «жесткая» и «смешанная» моделей), а также проблемы происхождения, современного развития и реализации принципа разделения властей как основы конституционного строя России. В завершении делается вывод о специфике российского варианта президентского конституционализма и возможностях его политического и конституционно-правового генезиса в контексте необходимости усиления республиканских и парламентских механизмов ответственности органов исполнительной власти на федеральном и региональном уровнях. Анализ российского республиканизма в контексте моделей разделения властей основывается на конкретно-историческом, сравнительно-правовом и формальноюридическом методах исследования. Перспективы развития и совершенствования республиканской формы правления и российского конституционализма автор связывает с применением метода конституционно-правового проектирования для усиления эффекта работы институтов парламентской и республиканской ответственности. Новизной исследования является разработка специфических черт различных моделей разделения властей в свете их отражения, реализации и перспектив развития в российской модели республиканской формы правления, а также идентификация правовой природы российского конституционализма (с учетом опубликованных ранее работ) и формулировка перспектив генезиса президентского конституиионализма в условиях смешанной республики с эффектом «гравитации кадровых полномочий» вокруг института Президента.
\end{abstract}

Ключевые слова: Республиканизм, форма правления, российский конституционализм, модели разделения властей, смешанная республика, президентский конституиионализм, Президент РФ, исполнительная власть, «гибкая», «жёсткая» модель, «смешанная» модель.

Abstract: The author explores the problem of identification of the Russian republicanism and constitutionalism, demonstrates the relationship between the constitutional form of government and models of separation of powers, open scientific approaches to understanding the nature and features of the republican form of government established by the Constitution of the Russian Federation in 1993. Particular attention is paid to the dynamic possibilities, realities and prospects of the development of the republican form of government in Russia. The study analyzes the theoretical basis, the origins of the principle of separation of powers, constitutional contours of the model of separation of powers ("flexible", "hard" and "mixed" models), as well as the problem of the origin, development and implementation of the modern principle of separation of powers as the basis of the constitutional order of Russia. The scientific novelty consists in the formulation of specific features of various models of separation of powers in light of their effect, implementation, as well as the future development of the republican form of government within the Russian model, including the identification of legal nature of the Russian constitutionalism.

Keywords: President of the Russian Federation, presidential constitutionalism, semi-presidential system, models of the separation of powers, Russian constitutionalism, form of government, republicanism, the executive branch, "flexible", "hard" model, "mixed" model. 


\section{Идентификация республиканской формы правления}

$\mathrm{M}$ одели современного конституционализма весьма разнообразны и тесным образом связаны с нормативными, институциональными и динамическими элементами конституционных форм правления. При этом под конституционными формами правления в данной статье понимаются модели формирования и взаимодействия главы государства, парламента и правительства, закреплённые в писаных конституциях или освященные конституционными обычаями или соглашениями.

На страницах научного юридической периодики открылась дискуссия о том, какая форма правления существует в современной России в контексте 20-летнего юбилея конституции и перспектив развития российского конституционализма $[1,2,3,4,5]$.

Республиканскую форму правления подтверждает и закрепляет в качестве основы конституционного строя ст.1 Конституции РФ 12 декабря 1993 года. Конституционный принцип республиканского правления основывается на признании суверенитета народа в качестве главной легитимирующей основы государственной власти. Республиканизм представляет такой государственный режим, при котором проводятся свободные выборы, и все высшие органы государственной власти формируются посредством демократических процедур или их деятельность легитимируется через представительные органы государства. Республиканская форма правления исключает возможность замещения должности главы государства (как и других публичных должностей) в порядке престолонаследия, однако может существовать в условиях монократического государства с пожизненным постом главы государства. Выборность как элемент республиканской формы правления может применяться в условиях монархии и порождать феномен выборной монархии.

Республиканская форма правления воплощается в виде президентской, парламентской или смешанной полупрезиденсткой, полупарламентской республики. Не всегда современные конституции закрепляют конкретную разновидность республики. Конституции, принятые в XVIII-XX вв., также порой не фиксировали вид республики (например, Конституция США 1787 года).

В начале 90-х годов XX века в конституционной юриспруденции России активно обсуждался вопрос о выборе формы правления для новой Конституции России. На завершающем этапе работы Конституционного совещания, когда заседала рабочая комиссия по доработке проекта Конституции РФ (в частности, 25 июня 1993 года), на повестке дня всё ещё стоял вопрос о выборе республиканской формы правления. Центр тяжести смещался либо в сторону парламентской республики, либо в сторону президентской республики. Выбор формы республики рассматривался, как «кардинальный вопрос, с которым окажется связанной не одна статья и не одна идея, а целая совокупность идей...» [6, с.36]. Выбор республиканской формы правления в 1993 году был детерминирован политическим обстоятельствами конфликта между законодательной и исполнительной властями и условиями разработки проекта Конституции РФ.

Российская конституция закрепила переход от республики Советов к представительному правлению, основанному на постоянной и профессиональной деятельности парламентариев. Наименование конкретной разновидности республиканской формы правления конституционные нормы не содержат. Возникает вопрос, в какой мере конституционная модель и реальный государственный режим приближается к президентской республике с элементами парламентаризма или парламентарной республике с элементами президенциализма или суперпрезидентской республике латиноамериканского типа? Эволюция формы правления в России началась в начале 90-х годов XX века и продолжается до сих пор, опираясь на Конституцию РФ.

В государственно-правовой и политической науках отсутствует единый взгляд на форму правления России и природу государственного режима после введения в действие новой Конституции РФ 1993 года. Спектр точек зрения охватывает как разновидность президентской республики (Б.Н. Топорнин) [7, с.64], так и смешанную “полупрезидентскую, полупарламентарную республику с доминирующим положением президента в структуре власти" (В.Е. Чиркин) [8, c.115]. Некоторые политологи утверждают, что в России установилась суперпрезидентская республика.

Следует поддержать взгляд о том, что новая Конституция России отражает процесс становления смешанной, или “гибридной” формы правления, которая относится к разряду нетипичных. В условиях данной формы правления сочетаются черты президентской и парламентской республики. Наряду с постом президента, обладающего значительным объемом дискреционных полномочий, существует правительство во главе с председателем, которому конституция вверяет осуществление исполнительной власти. Доминирование главы государства, который не включается в структуру исполнительной 
власти, но наделяется широким перечнем характерных для неё полномочий, свидетельствует о преемственности неизжитой традиции сильной единоличной власти (в имперский период - монархической, а в советский - неформальной монократической) в истории России. Президент РФ легально ограничен в использовании права роспуска нижней палаты парламента. Конституция РФ в ст.111 и 117 закрепляет исчерпывающий перечень оснований роспуска Государственной Думы и обязывает Президента, чтобы вновь избранная Государственная Дума собралась не позднее чем через четыре месяца с момента роспуска (ч.1 и 2 ст. 109). Сравнительно-правовой анализ показывает, что президент Франции, где существует смешанная полупрезидентская республика, не ограничен легальным перечнем оснований роспуска Национального собрания.

Согласно ст.103 Конституции РФ Государственная Дума дает согласие Президенту РФ на назначение Председателя Правительства. Однако в назначении федеральных министров Президент не связан согласием нижней палаты российского парламента. Государственная Дума может три раза отклонить представленные кандидатуры Председателя Правительства, после чего Президент назначает Председателя Правительства, распускает Государственную Думу и назначает новые выборы (ч.4 ст.111). Конфликт, который может возникнуть между главой государства и нижней палатой парламента по поводу одобрения кандидатуры на пост Председателя Правительства, Конституция ориентирует на разрешение в пользу Президента, а согласие Думы на назначение главы правительства превращается фактически из права в обязанность. Правительство РФ во многом сохраняет политически независимое положение по отношению к парламенту, т.к. его деятельность не обусловлена позитивной формулировкой обязательного доверия со стороны Государственной Думы. Правительство РФ не обязано получать инвеституру со стороны нижней палаты парламента для осуществления исполнительно-распорядительной деятельности.

В юридической литературе стала распространенной точка зрения о формировании в России при ограниченном характере контрольных полномочий парламента особой “президентской власти”, которая не входит в структуру исполнительной власти. Формирование особой президентской власти, при которой Президент РФ занимает позицию верховного арбитра, стоит «над» всеми ветвями власти, подтверждают намерения разработчиков президентского проекта Конституции РФ [9, с.138].
Принимая во внимание комплексный характер президентских полномочий, следует учитывать, что фактически исполнительная власть в России является бицефальной. Лидирующее положение в отношениях Президент РФ - Председатель Правительства РФ занимает глава Российского государства. В период 2008-2012 годов центр исполнительной власти переместился к Председателю Правительства РФ. Начиная с 2012 года после выборов Президента РФ, глава государства вновь стал занимать лидирующие позиции в сфере исполнительно-распорядительной деятельности. Политическая конкуренции и элементы социально-политического противоборства, которые в принципе возможны в рамках дуалистической модели организации исполнительной власти (как например, в полупрезиденсткой республике во Франции), отсутствуют в российской конституционно-политической практике в связи с существованием не «разделённого правления» или «периода сосуществования», а политического дуумвирата с перемещаемым центром государственной власти по линии Президент РФ Председатель Правительства РФ.

При этом Конституция РФ исходит из дискреционного характера полномочий Президента РФ во взаимоотношениях с Правительством РФ. В отношении актов главы государства российское конституционное право не предусматривает института контрассигнатуры, что в целом характерно для президентской республики, в которой президент является главой исполнительной власти (например, США). В конституционной системе России действуют и глава государства, и Председатель Правительства РФ. Для обеспечения большей согласованности не только их действий, но и всей исполнительной власти, по-видимому, необходимо определить, какие акты Президента РФ издаются им самостоятельно, а какие требуют скрепы Председателя Правительства РФ или соответствующего министра. Тем самым повысилась бы ответственность министров за взятые ими на себя обязательства, а также скоординированность действий внутри исполнительной власти. Существующая в России смешанная республика стала бы более рациональной.

Развитие конституционного строя современной России немыслимо без правового оформления института конституционной ответственности министров, конкретные формы которой могут быть весьма разнообразны. Его введения требовали в начале XX века конституционалисты и либеральные государствоведы и с его наличием связывали существование полноценного конституционного строя. В соответствии с п. "б” ч.1 ст.103 Конституции РФ к 
ведению Государственной Думы относится решение вопроса о доверии Правительству. Нижняя палата Федерального Собрания наделяется возможностью выразить вотум недоверия Правительству в целом за политическую нецелесообразность его действий. Государственный режим сохраняет черты дуалистической системы, хотя конституционная регламентация права нижней палаты выражать недоверие Правительству означает возникновение отдельных элементов системы парламентаризма.

После внесения поправки в Конституцию РФ в 2008 году (в П. «а» ч.1 ст.114), Правительство РФ представляет Государственной Думе ежегодные отчеты о результатах своей деятельности, в том числе по вопросам, поставленным Государственной Думой (Закон Российской Федерации о поправке к Конституции Российской Федерации от 30 декабря 2008 г. N 7-ФКЗ «О контрольных полномочиях Государственной Думы в отношении Правительства Российской Федерации», вступившим в силу со дня его официального опубликования 31 декабря 2008 г.) [10]. В период с 2009 по 2013 годы сформировалась практика выступления Председателя Правительства РФ с отчетами перед депутатами Государственной Думы. Такие отчеты проходят в апреле за предыдущий год деятельности правительства.

Ежегодные отчёты Правительства РФ содействуют политической оценке деятельности Правительства РФ депутатами нижней палаты Парламента РФ.

Конституция РФ устанавливает (ч.4 ст.3), что «никто не может присваивать власть в Российской Федерации». Захват власти или присвоение властных полномочий преследуются должны преследоваться по федеральному закону. Таким законом стал УК РФ. Согласно статье 278 УК РФ («Насильственный захват власти или насильственное удержание власти»), действия, направленные на насильственный захват власти или насильственное удержание власти в нарушение Конституции Российской Федерации, а равно направленные на насильственное изменение конституционного строя Российской Федерации, наказываются лишением свободы на срок от двенадцати до двадцати лет с ограничением свободы на срок до двух лет.

\section{Принцип разделения властей как основа конституционного строя}

Теоретические основы и истоки принциипа разделения властей. Принцип разделения властей является не только основой конституционного строя, но принципом российского конституционализма. Он тесным образом связан с существованием политической свободы и предотвращением угрозы концентрации власти в одних руках и поэтому в значительной степени способен повлиять на устойчивый характер власти. Этот принцип определяет построение институциональных средств власти или механизма государственной власти.

Доктрина разделения властей не стояла на месте, постоянно развивалась вместе с конституционными институтами и в современном конституционном праве ее не следует понимать упрощенно. Как отмечает Роберт Френч, существует соблазнительная простота триединой метафоры правления, в соответствии с которой парламент создает законы, исполнительная власть их исполняет и суды интерпретируют их [11, p.2]. В современных демократических государствах этот принцип корректируется такими конституционными институтами, как конституционное правосудие, политический плюрализм, судебный надзор за правовыми актами. Целостно развитый Ш. - Л. Монтескье принцип разделения властей, так или иначе, получил конституционное закрепление в большинстве конституций государств Европы и Америки. По мнению автора теории разделения властей Ш. - Л. Монтескье, угроза концентрации власти и, как следствие, злоупотребление ею может быть предотвращено путем деления власти на законодательную, исполнительную и судебную [12, с.290-291]. Разделение властей в современной интерпретации по праву можно считать одним из основных принципов конституционализма. Этот принцип имеет особенное значение не только в общей теории конституционализма, но и, что значительно важнее, в практике осуществления властных функций.

Учение о разделении властей, разработанное Ш. - Л. Монтескье, продолжившим идеи Дж. Локка, является составной частью демократического развития, активным инструментом борьбы за политическую свободу. Оно с успехом использовалось в странах западной демократии и в Америке, но в условиях российской (периода СССР) действительности продолжительное время считалось неприемлемым. Взгляд на идею разделения властей как на чисто буржуазную теорию, препятствовал объективной оценке её позитивных качеств, привнесенных как классиками этого учения, так и их последователями (в Америке - Дж. Мэдисоном, А. Гамильтоном, Т. Джефферсоном), исходившими не столько из узких интересов буржуазии, сколько из общечеловеческих ценностей движения к политическому равенству и свободе. 
Как правовой принцип разделение властей впервые был закреплен в конституционном законодательстве России в Декларации о государственном суверенитете РСФСР от 12 июня 1990 года. В п.13 Декларации говорилось, что разделение законодательной, исполнительной и судебной властей является важнейшим принципом функционирования РСФСР как правового государства [13]. Затем этот принцип в порядке дополнения был введен в Конституцию 1978 года. Закрепление в Конституции Российской Федерации (ст.10) разделения властей как основы конституционного строя России стало окончательным преодолением негативного отношения к этому принципу со стороны политиков и правоведов. Принцип разделения властей становится основным в структуре функционирования политических институтов государства и общества с учетом принципов взаимного сдерживания и взаимного сотрудничества властей.

Принцип разделения властей получает своё развитие в теории динамического равновесия, согласно которой для поддержания баланса властей каждая власть наделяется собственной компетенцией независимо от других властей, закрепляется самостоятельность правового статуса каждой ветви власти при осуществлении своих полномочий и каждая ветвь власти наделяется возможностью противопоставить своё мнение решению другой ветви. Идею равновесия отстаивает в своей работе А.М. Барнашов [14, с.66]. Между тем равновесие в условиях взаимодействия властей не может быть статическим и к тому же полным, баланс властей в рамках конституционной системы может изменяться благодаря социальнополитическим факторам или конституционному толкованию. Поэтому предпочтительнее говорить о динамическом равновесии, как отражающем реальный процесс взаимодействия властей. Под динамическим равновесием в литературе понимается такое состояние, когда дисбаланс ветвей власти находится в пределах, определенных конституцией, и оно может быть изменено результатами выборов или иначе истолковано судами [15, с.83].

Об опасности, таящейся в объединении всех ветвей власти в одном органе, предупреждали и Дж. Мэдисон, и Т. Джефферсон, отстаивавшие необходимость доминирующего во всей политической системе принципа разделения властей. Так, Дж. Мэдисон в 47-м номере «Федералиста» утверждал: «Сосредоточение всей власти - законодательной, исполнительной и судебной - в одних руках, независимо от того, предоставлена ли она одному лицу или многим, по наследству, назначению или избранию, можно по праву определить словом «тирания» $[16$, c.323]. В свою очередь, Т. Джефферсон критиковал Конституцию 1776 года штата Вирджиния за узурпацию власти законодательным органом: «Все ветви власти - законодательная, исполнительная и судебная - сходятся в законодательном органе. Средоточие их в одних и тех же руках как раз и определяет деспотическое правление. Ничуть не будет легче, если вся эта власть находится в руках многих, а не кого-то одного. 173 деспота несомненно, будут угнетать так же, как и один» [17, с.196]. Поэтому выборный деспотизм, как и любой другой деспотизм, в не меньшей степени может нарушать автономию личности и деформировать власть. Преградой ему должен служить принцип разделения властей. По мнению Т. Джефферсона, в основу организации властных структур необходимо положить принцип жесткого разделения властей, с тем чтобы ни один человек не был носителем более чем одной формы власти одновременно [18, с.84].

Вся власть в обществе, согласно теории равновесия, должна быть разделена и уравновешенна таким образом, чтобы ни один институт власти не занял доминирующего положения по отношению к другим и не смог выйти за рамки законных полномочий других институтов власти. Таким образом, отношения, складывающиеся в государственной сфере между законодательными, исполнительными и судебными органами, должны основываться, с одной стороны, на разделении (и в этом смысле обособлении их компетенции), с другой стороны, - на взаимопроникновении с целью контроля и равновесия, чтобы ни один орган с полномочиями власти не оказался надо всей государственной системой, не вырос в такую самодовлеющую силу, которая смогла бы подмять под себя всю пирамиду власти.

Задаче поддержания равновесия в концепции разделения властей служит система “сдержек и противовесов”. Первоначально разработанная Ш. Л. Монтескье, она не обеспечивала эффективного сотрудничества между властями в решении государственных дел и не предусматривала создания действенного механизма для решения возможных коллизий. Преодоление возможной бездейственности такого механизма было осуществлено основателями Конституции США 1787 года.

В российской государственной жизни система “сдержек и противовесов” только складывается. Нарабатывается опыт использования конституционных норм, закрепляющих различные сдержки и противовесы. Нередко этот опыт возникает в условиях политической борьбы или противостояния ветвей власти. Например, использование Президентом РФ права вето на законопроекты, принятые Федеральным 
Собранием, выявило проблему соотношения президентского права отклонить проект и обязанности подписать в установленный срок в случае преодоления несогласия Президента РФ в ходе повторного голосования Парламентом России. Другая проблема возникла в связи с неодинаковым пониманием Государственной Думой и Президентом РФ вопроса о том, сколько раз вправе глава государства вносить в нижнюю палату одну и ту же кандидатуру на пост главы Правительства. И в том, и в другом случае спорные и проблемные вопросы были разрешены в результате осуществления толкования Конституции органом конституционного правосудия. В первом случае Конституционный Суд указал, что Президент обязан подписать законопроект в установленный Конституцией срок, даже если считает его не соответствующим Конституции. После этого он вправе направить в Конституционный Суд запрос о проверке его конституционности. Тем самым Конституционный Суд признал, что конституционные обязанности Президента стоят выше мотивов неконституционности принятых Парламентом актов. Во втором случае Конституционный Суд в спорной ситуации отдал предпочтение президентской стороне и фактически конституировал право Президента вносить в Государственную Думу одну и ту же кандидатуру три раза. Такое решение вызвало обширную конституционную дискуссию, вследствие которой ряд ученых и политиков высказался критически по отношению к правовой позиции Конституционного Суда. Если подходить к этому решению с позиций перспективы развития элементов парламентаризма, то позиция Конституционного Суда создает определенные ограничения этому вектору развития.

Тем не менее, представляется, что первый опыт наработки фактического использования сдержек и противовесов важен и поучителен для обновленного конституционного права России. Следует отметить, что система «сдержек и противовесов» включает такие особые правовые процедуры, которые являются связующими звеньями между различными ветвями власти. Именно поэтому разделение властей поддерживается подобной системой, а её существование объясняется необходимостью налаживания отношений сотрудничества между законодательной, исполнительной и судебной властями, т.е. система “сдержек и противовесов" есть механизм взаимодействия разделенных прежде властей. И законодательную, и исполнительную, и судебную власти разделить необходимо, но не для того, чтобы окончательно обособить друг от друга, а лишь для направления их деятельности к взаимодействию и сотрудничеству.
Требование, чтобы при вынесении важных решений одна ветвь власти сходилась во мнении с другой ветвью, служит одним из способов преодоления чрезмерной концентрации власти [19, c.69]. Определенно правильным является такое положение вещей, при котором, связывая три ветви власти в единый взаимодействующий механизм, функционирование системы “сдержек и противовесов” стабилизирует работу всех органов государства. Тем не менее, обеспечение взаимного сотрудничества - возможная, но не единственная задача практического применения этой системы. Каждая из трех властей обладает прерогативами в области законодательства, исполнения и суда соответственно. Поэтому сдерживание чрезмерного воздействия одной власти на другую не менее важно для успешного осуществления ими собственных полномочий. Прерогативы как исключительные права одной власти должны быть ограждены от проникающего влияния других властей. Поиск баланса властей - это постоянно возобновляющийся процесс, который в то же время должен иметь конституционные рамки.

Тот факт, что многие из современных демократических государств в основу механизма государственной власти положили принцип разделения властей, доказывает его живучесть и действенность. Как справедливо отмечает А. Янов, до Монтескье политическая система всегда строилась по вертикальному признаку, представляя собой более или менее совершенную иерархию, “подобно готическому собору венчавшуюся шпилем - единоличным лидером” [20, с.88]. Этим лидером мог быть князь, царь, король. Принцип политической вертикали максимизировал возможность возрождения авторитарного режима. Современные конституционные режимы используют модель политической вертикали для определения конституционных и реальных прерогатив органов государственной власти, их политического доминирования в системе органов государственной власти.

Ш. - Л. Монтескье был одним из первых, предложивших новый принцип построения политической системы, именно принцип политической горизонтали. В основе этого принципа лежат три равноправных, уравновешивающих друг друга института власти. Такая система сложна и первоначально мало эффективна, она может служить устойчивому развитию общества после того, как пустит корни в политическую культуру и обыденное сознание населения. Вместе с тем, формирование именно такой политической системы позволяет минимизировать вероятность возрождения тирании. 
Модели разделения властей: конституционные контуры.

В современных конституционных государствах сложились разнообразные модели реализации принципа разделения властей: “гибкая”, “жесткая”, “смешанная”. Ряд исследователей читают, что существует две модели: гибкая и жесткая [14, с.67]. Данная терминология используется с целью выявления характерных особенностей каждой модели разделения властей и вместе с тем для определения общих черт, свойственных целой группе государств, функционирующих в условиях одной из названных моделей. В современных конституционных исследованиях модели разделения властей чаще привязываются к определенной форме правления, в рамках которой та или иная модель существует. Например, Л.М. Энтин в своей книге рассматривает разделение властей в президентской республике (американский вариант), разделение властей в парламентарных монархиях и республиках, разделение властей в странах со смешанной формой правления (опыт французской республики), разделение властей в развивающихся странах [21]. Такой подход нацелен показать взаимосвязь между конституционно установленным распределением полномочий между органами государственной власти и существующей в государстве формой правления.

Сходный подход представлен в работе В.В. Лузина, который проводит сравнительное исследование о принципе разделения властей в государственном механизме США, Великобритании и Франции, выделяя три модели разделения властей: президентскую модель (на примере США), парламентарную модель (на примере Великобритании), полупрезидентскую модель (на примере Франции) [22, с.7]. В сущности, в условиях конституционализма определенная модель разделения властей становится содержательным элементом и конституционным атрибутом определённой формы правления, хотя полностью не сливается с ней.

«Гибкая» модель берет свое начало в учении Дж. Локка о тесном сотрудничестве и взаимодействии властей при верховенстве одной из них. Она характерна для стран с парламентарной формой правления. Примерами могут служить как парламентарные монархии (Великобритания), так и парламентарные республики (Италия, Германия). Применительно к Австралии юристы отмечают, что настоящая реальность адекватно описывается там как частичное разделение властей, если речь идет о взаимоотношениях законодательной и исполнительной ветвей власти.
Гибкая модель разделения властей тесным образом связана с теорией и практикой парламентаризма в различных вариациях, существующих как в рамках Вестминстерской модели, так и континентальных разновидностей. Ей присущи следующие черты. 1) Конституционное право провозглашает доктрину верховенства парламента. 2) Правительство формируется парламентским способом и несет политическую ответственность перед парламентом. 3) Должность премьер-министра занимает лидер партии парламентского большинства или лидер коалиционного большинства в парламенте. 4) Конституционные конфликты, возникающие между правительством и парламентом, разрешаются с помощью средств обоюдного воздействия: правительство может применить право роспуска парламента, а парламент вправе выразить правительству недоверие, тем самым, привлекая его к политической ответственности. 5) В рамках гибкой модели, как правило, осуществляется единое политическое руководство страной, т.к. одна и та же политическая партия или коалиция партий контролирует и парламент и правительство.

«Жесткая» модель восходит к доктрине Ш. - Л. Монтескье и опирается на идеи Дж. Мэдисона, А. Гамильтона, Т. Джефферсона о равновесии, независимости и взаимном контроле властей. Эта модель впервые осуществлена в США, согласно Конституции 1787 года. Для жесткой модели разделения властей характерны следующие черты, которые, тем не менее, могут иметь различные модификации в отдельных странах.

1) Органы законодательной и исполнительной властей формируются самостоятельно и независимо друг от друга и имеют свой собственный электорат, при этом сроки их полномочий не совпадают во времени. 2) Одно и тоже должностное лицо может быть носителем только одной формы власти одновременно, поэтому устанавливается конституционный запрет на совмещение депутатского мандата, министерского портфеля и должности судьи. 3) Органы законодательной и исполнительной властей не могут определяющим образом влиять на досрочное прекращение полномочий друг друга по политическим мотивам: глава государства не может распустить парламент, а парламент не может выразить недоверие правительству. 4) В конституционные основы жесткой модели разделения властей заложена возможность разделенного политического правления, которое наступает всякий раз, когда президентскую власть контролирует одна политическая партия, а большинство в одной или обеих палатах парламента принадлежит другой политической партии. 


\section{Государственные институты и правовые системы}

«Смешанная» (или полупрезидентская) модель появилась в XX веке благодаря сочетанию элементов гибкой и жесткой моделей [23]. Эта модель предусматривает значительную подвижность политического режима без изменения ее конституционных основ. В рамках смешанной модели разделения властей фактически могут существовать два политических режима президентско-парламентский и парламентско-президентский. Характерным примером реализации смешанной модели разделения властей во второй половине XX столетия стал конституционный опыт функционирования V Республики во Франции, учрежденной Конституцией 1958 года.

Наиболее важными чертами этой модели являются следующие. 1) Исполнительная власть является «бицефальной», т.е. глава государства (президент) и правительство, возглавляемое премьер-министром, обладают как самостоятельными (дискреционными), так и совместными полномочиями. 2) По конституции Президент самостоятельно формирует правительство, однако в политической практике важное значение приобретает мажоритарный фактор в парламенте. Если большинство в нижней палате поддерживает Президента, то и правительство формируется главой государство. Если большинство принадлежит другой партии, то Президент вынужден формировать правительство с учетом этого большинства и назначать премьерминистром лидера партии парламентского большинства. 3) Президент пользуется правом роспуска нижней палаты парламента по политическим соображениям, подкрепленным конституционными обычаями. 4) Правительство реально несет двойную ответственность перед Президентом и нижней палатой парламента. При этом в каждом конкретном случае возможно преобладание той или иной формы ответственности в зависимости от расстановки политических сил в парламенте.

Следовательно, можно сделать вывод, что идеальный тип, выработанный Ш. - Л. Монтескье, в различных демократических государствах трансформировался под влиянием особенностей правовой и политической культуры народов, специфики эволюции государственно-правовых институтов при переходе к конституционному строю. Конституционная система разделения властей в России отвечает требованиям сильной исполнительной власти, однако предоставляет недостаточно контрольных полномочий парламенту за деятельностью правительства. Дальнейшее её развитие потребует введения конституционной ответственности министров, без которого полноценный конституционный строй вряд ли возможен.

\section{О разделении властей в российской системе конституционализма.}

В советский период принцип разделения властей отвергался, вследствие чего тесно связанные с ним принципы конституционной демократии о порядке взаимоотношений законодательных, исполнительных и судебных органов государственной власти не признавались доктриной и практикой советского строительства. Преобладало мнение о ненужности в Советском государстве политической ответственности правительства, административной юстиции и других механизмов, сдерживающих деятельность должностных лиц и обязывающих их действовать исключительно на основе законности.

Советское государствоведение основывалось на концепции единства государственной власти. Эта концепция противопоставлялась доктрине и практике разделения властей. Нередко такое противопоставление приводит к неправильному пониманию соотношения проблемы единства государственной власти и ее разделения. Как представляется и в условиях демократического конституционализма реализация принципа разделения властей не исключает, а предполагает определенное единство государственной власти.

Вопрос об единстве государственной власти следует рассматривать в двух аспектах. Во-первых, в условиях демократического конституционного государства органы государственной власти имеют один источник легитимации и функционируют в рамках единой конституционной системы. Следовательно, в организационно-функциональном плане конституционные органы государства обладают определенным единством, функциональными связями, которые позволяют сохранять сбалансированное развитие и осуществление полномочий. Помимо этого, даже разделение властей требует единства государственной политики, осуществляемой различными органами, единства действий всех ветвей по принципиальным вопросам общественного развития.

Во-вторых, концепция единства государственной власти может использоваться для обоснования различных видов авторитарного правления. В условиях абсолютной монархии единство власти выводилось из полновластия монарха, который провозглашался верховным органом и единственным источником властей в государстве. Все другие органы наделялись полномочиями, производными от монарха. В российском абсолютизме такому порядку вещей соответствовало деление органов государства на органы верховного и подчиненного управления [24, с.1-7]. 
Доктрина и практика советского строительства опиралась на принципиально иной источник легитимации государственной власти. Идейными истоками концепции единства государственной власти, существовавшей в Советском государстве, были взгляды Ж.Ж. Руссо о предоставлении неограниченной и суверенной власти одному государственному органу, которым должен быть орган народного представительства. Помимо этого использовались опыт Парижской коммуны, концепция «работающей корпорации» и отражение в государственном механизме только воли одного господствующего класса. Такой идейный фундамент, положенный в основу единства государственной власти в условиях советского строительства, создал предпосылку для постепенной монополизации власти единственной правящей партии, которая осуществляла политический контроль за системой Советов и иных государственных органов. Этот опыт показывает, что реальное разделение властей невозможно осуществить без политического плюрализма в условиях современной демократии.

Установленная в Конституции РФ 1993 года модель разделения властей типологически близка к «смешанному» варианту, в котором сочетаются элементы жесткой и гибкой моделей. По отношению к российской модели разделения властей можно провести исторические параллели: сходные модели действовали в различных политических и социально-экономических условиях Веймарской Германии согласно Конституции 1919 года вплоть до прихода к власти национал-социалистов в 1933 году и в V Французской Республике по Конституции 1958 года. Последствия введения такой модели в Германии и во Франции были различными, что показывает ее вариативность в процессе реализации конституционных норм, влияние на нее факторов демократической консолидации, устойчивой партийной системы и конституционного толкования.

Можно выделить три внутренних политических условия, определивших введение смешанной модели разделения властей. Во-первых, потребность существования у Президента функции «дирижера-арбитра» во взаимоотношениях с другими органами государства, в первую очередь с Правительством и Парламентом. Президент в этом случае выступает и основным координатором всей преобразовательной деятельности государства. В общей теории разделения властей существование главы государства часто связывают с потребностью «цементировать государственную власть», «обеспечивать разрешение кризисов и конфликтов между органами государственной власти» конституционным спо- собом [25, с.135]. Применительно к России такая потребность также ощущалась после политического и вооруженного конфликта осенью 1993 года и введения в действие новой Конституции. Во-вторых, победный характер Конституции РФ 1993 года в значительной степени предопределил явный перевес Президента в системе органов государственной власти. В-третьих, в историческом плане учитывались и некоторые правовые традиции думского периода начала XX века. В дальнейшем конституционном развитии России победный характер Конституции РФ и отсутствие в ней прямого закрепления вида республики позволили широко интерпретировать конституционные положения, особенно в отношении прерогатив и так называемых «скрытых» и законодательно установленных полномочий Президента РФ. Интересные размышления о характере и объеме президентских полномочий в контексте развития и даже «преобразования» Российской Конституции представлены в работах М.А. Краснова [26, 27, 28, 29]. В своих работах он подходит к анализу полномочий главы государства в контексте конституционных конструкций «властных треугольников» [29]. Анализ конституционных конструкций “властных треугольников” в странах, закрепляющих смешанную форму правления, позволяет, по его мнению, вывести три модели, демонстрирующие степени эффекта “компетенционной гравитации”. Россия со своим президентским образом “компетенционной гравитации” тяготеет к третьей модели с бесконтрольной гравитацией. По его мнению, его основная причина тяготения к третьей модели - отсутствие реальных сдержек и противовесов “политико-кадровым” полномочиям главы государства. Усиливается этот эффект конституционным закреплением президентских функций, выходящих за рамки предназначения главы государства, и полномочий, не вытекающих из президентских функций. Это выражается как в президентском нормотворчестве, так и в законодательном наделении главы государства новыми полномочиями в совершенно разных сфеpax [29, с.91]. М.А. Краснов считает, что эффект от третьей модели формально может быть признан в целом соответствующим Конституции (за исключением некоторых конкретных полномочий), но явно противоречит идее конституционализма и ведет к укреплению потестарного типа государственности, не давая появиться и развиваться правовому типу.

На наш взгляд, конституционная модель смешанной республики допускает высокую степень подвижности или динамизма реального государственного режима и объема властных прерогатив главы госу- 
дарства. Российский вариант смешанной республики следует рассматривать не только в контексте сравнительно-правового и конституционного-политического анализа, основанного на страноведческом подходе, но и опираясь на российскую государственно-правовую традицию XIX-XX веков, особенно обращая внимание, что конституционные модели «треугольников государственной власти» в условиях российских конституционных экспериментов в XX веке всегда подвергались существенным искажениям, или «гравитации» в сторону главы государства.

Из двух возможных режимов в рамках смешанной модели российский государственный режим в период президентства Б.Н. Ельцина и на современном этапе правления В.В. Путина тяготеет к президентско-парламентскому режиму. Для российской конституционной модели характерны следующие черты.

Президент РФ избирается всеобщими выборами, получая мандат непосредственно из рук избирателей, и поэтому может противопоставить себя Парламенту, оказывая на него политическое давление. Правительство РФ формируется непосредственно Президентом РФ, при этом отсутствует обязанность учитывать расстановку политических сил (в лице депутатских объединений) в Государственной Думе по результатам выборов в нижнюю палату. Требование о согласии Государственной Думы на назначение распространяется только на пост Председателя Правительства РФ. Данное правило в перспективе способно усилить элементы парламентаризма в российской модели разделения властей, если в Государственной Думе будет формироваться устойчивое партийное большинство. Такой мажоритарный фактор в парламенте может воздействовать на возникновение конституционного обычая, подобного французскому, и в соответствии с которым Президент при назначении главы Правительства учитывает, какой из политической партии принадлежит большинство мест в нижней палате Парламента. Политическая ответственность Правительства перед Государственной Думой, хотя закреплена в конституционных нормах, пока носит призрачный характер, - реально Правительство отвечает перед Президентом. Этот инструмент не может быть реально действующим, пока не оформится практика учета мажоритарного фактора в Парламенте. Декретировать такую конституционную практику вряд ли возможно, она должна сложиться в результате постепенной политической эволюции [9, с.137-143]. Смешанная модель разделения властей предоставляет такую возможность, т.к. более подвижна и вариативна по сравнению с президентской или классической парламентской моделью. С этих позиций избранная в России конституционная модель разделения властей, хотя и нуждается в усовершенствовании, тем не менее, позволяет производить их не в процессе кардинальной ломки, а в ходе конституционной эволюции и реформы.

Специфика смешанной республики в России заключается в том, что в конституционно-политических реалиях осуществления государственной власти возник эффект президентского конституционализма. С генетической точки зрения данное политико-правовое явление опирается как на историческую публичную традицию монархического конституционализма (опыт думской монархии и роль главы государства), так и на победный характер Российской Конституции, которая определила на несколько десятилетий вперёд доминирование Президента РФ, тяготение или «гравитацию» публичной власти к персоне главы государства.

Происхождение Российской конституции связывает историческую перспективу развития российского конституционализма и республиканской формы правления возвышением и обособлением президентской власти. Политический феномен президентского конституционализма проявляется эффектом публично-политического дуумвирата главы Российского государства и главы правительства, который сочетается с кадровым доминированием главы государства в вопросах формирования системы (и структуры) федеральных органов государственной власти, органов со специальной компетенцией (Счетной палаты, Прокуратуры РФ, Центрального Банка России).

Президентский конституционализм искажает принципы республиканизма, однако позволяет концентрировать ответственность различных органов государства (Правительства в целом, отдельных руководителей федеральных органов исполнительной власти, высших должностных лиц субъектов РФ и др.) перед Президентом РФ.

С точки зрения возможностей политического и конституционно-правового генезиса президентский конституционализм нуждается в усилении республиканских и парламентских механизмов ответственности. Поэтому судьба российского варианта президентского конституционализма во многом будет зависеть от его способности трансформироваться в республиканскую форму правления с развитыми и конституционно и законодательно оформленными институтами парламентской ответственности органов исполнительной власти как на федеральном, так и на региональном уровнях организации публичной власти. 


\section{Библиография:}

1. Чиркин В.Е. Какая форма правления существует в современной России? // Российский журнал правовых исследований. 2014. № 4 (1). С.32-40.

2. Кравец И.А. Судебное гарантирование конституции и президентский конституционализм // NB: Вопросы права и политики. 2014. - № 8. - C.1-35. DOI: 10.7256/2305-9699.2014.8.12780. URL: http://e-notabene.ru/lr/article 12780.html.

3. Колюх В.В. Дуализм исполнительной власти: конституционные предпосылки и средства ограничения // Право и политика. - 2015. - № 6. - C. 759-765. DOI: 10.7256/1811-9018.2015.6.15285.

4. Бондарь Н.С. По какой Конституции живет Россия: прошлого или нынешнего, XXI века? // Журнал зарубежного законодательства и сравнительного правоведения / Journal of foreighn legislation and comparative law. - 2013. - №6. - C. $976-985$.

5. Кочетков В.В. Русские ценности и российская Конституция 1993 года // Право и политика. - 2013. - №13. - С. 18551865. DOI: 10.7256/1811-9018.2013.13.9736.

6. Конституционное совещание. Стенограммы. Материалы. Документы. Т. 15. М., 1996. С.36.

7. Топорнин Б.Н. Вступительная статья // Конституция Российской Федерации: Научно-практический комментарий/ Под ред. акад. Б.Н. Топорнина. М., 1997. С.64.

8. Чиркин В.Е. Нетипичные формы правления в современном государстве // Государство и право. 1994. № 1. С.115.

9. Шахрай С.М. О Конституции: Основной закон как инструмент правовых и социально-политических преобразований. M., 2013.

10. Российская газета. 2008, 31 декабря.

11. French R. Parliament, the executive, the courts and the people // Deakin Law Review. 1996. Vol.3. No.1. P.2.

12. Монтескье Ш. - Л. О духе законов // Монтескье Ш. - Л. Избранные произведения. М., 1955. С.290-291.

13. Россия сегодня. Политический портрет в документах. Вып.2. / Отв. ред. Б.И. Коваль. М., 1993. С.23.

14. Барнашов А.М. Теория разделения властей: становление, развитие, применение. Томск, 1988.

15. Шайо А. Самоограничение власти (краткий курс конституционализма): Пер. с венг. М.: Юрист, 2001. С.83.

16. Федералист. Политические эссе А. Гамильтона, Дж. Мэдисона и Дж. Джея: Пер с англ. / Под общ. ред., с предисл. Н.Н. Яковлева. М.: Издательская группа «Прогресс»- «Литера», 1993. С.323.

17. Джефферсон Т. Автобиография. Заметки о штате Виргиния. Л.: Наука, 1990. С.196.

18. Джефферсон Т. О демократии. / Сост. Сол К. Падовер. СПб.: Лениздат, 1992. С.84.

19. Верховенство права. М., 1992. С.69.

20. Янов А. Монтескье против Маркса // Общественные науки и современность. 1992. № 1. С.88.

21. Энтин Л.М. Разделение властей: опыт современных государств. М.: Юрид. лит., 1995.

22. Лузин В.В. Принцип разделения властей как основа конституционализма. Н.Новгород, 1997. С.7.

23. Лузин В.В. Полупрезидентская модель разделения властей (на примере Франции) // Право и политика. Международный научный журнал. 2000. № 1. С.31-40.

24. Коркунов Н.М. Русское государственное право. Т.ІІ. Часть особенная. СПб., 1903. С.1-7.

25. Чеботарев Г.Н. Принцип разделения властей в государственном устройстве Российской Федерации. Тюмень, 1997. C.135.

26. Краснов, М. А. Персоналистский режим в России: опыт институционального анализа/ М. А. Краснов. - М.: Фонд «Либеральная миссия», 2006. - 180 с.

27. Краснов, М. А. Статус главы государства как элемент авторитарного потенциала президента / М. А. Краснов // Государство и право. - 2015. - № 1. - С. 5-16; № 2. - С. 5-17.

28. Краснов М.А. Законодательно закрепленные полномочия Президента России: необходимость или сервилизм? // Сравнительное конституционное обозрение. 2011. № 4.

29. Краснов М.А. Президент в экономике: эффект “компетенционной гравитации”// Общественные науки и современность. - 2014. - № 1. С.77-92.

30. А. Д. Керимов, Е. В. Халипова Правомерно ли выделение лишь трёх ветвей государственной власти? // Политика и Общество. - 2012. - 3. - С. $42-48$.

31. Арутюнян Г.Г. Консититуционализм в контексте конституционной культуры нового тысячелетия // Журнал зарубежного законодательства и сравнительного правоведения / Journal of foreighn legislation and comparative law. - 2013. - 5. - С. $773-779$.

32. А.В. Безруков Роль Президента России в механизме реализации конституционных принципов федерализма, единства государственной власти и разделения властей // Политика и Общество. - 2013. - 3. - С. 263 - 269. DOI: 10.7256/18128696.2013.03.2.

\section{References (transliterated):}

1. Chirkin V.E. Kakaya forma pravleniya sushchestvuet v sovremennoi Rossii? // Rossiiskii zhurnal pravovykh issledovanii. 2014. № 4 (1). S.32-40.

2. Kravets I.A. Sudebnoe garantirovanie konstitutsii i prezidentskii konstitutsionalizm // NB: Voprosy prava i politiki. 2014. - № 8. - S.1-35. DOI: 10.7256/2305-9699.2014.8.12780. URL: http://e-notabene.ru/lr/article_12780.html.

3. Kolyukh V.V. Dualizm ispolnitel'noi vlasti: konstitutsionnye predposylki i sredstva ogranicheniya // Pravo i politika. - 2015. - № 6. - S. 759-765. DOI: 10.7256/1811-9018.2015.6.15285. 
DOI: $10.7256 / 1811-9018.2016 .1 .16285$

При цитировании этой статьи сноска на dоі обязательна

Государственные институты и правовые системы

4. Bondar' N.S. Po kakoi Konstitutsii zhivet Rossiya: proshlogo ili nyneshnego, XXI veka? // Zhurnal zarubezhnogo zakonodatel'stva i sravnitel'nogo pravovedeniya / Journal of foreighn legislation and comparative law. - 2013. - №6. - C. $976-985$.

5. Kochetkov V.V. Russkie tsennosti i rossiiskaya Konstitutsiya 1993 goda // Pravo i politika. - 2013. - №13. - C. 1855-1865. DOI: 10.7256/1811-9018.2013.13.9736.

6. Topornin B.N. Vstupitel'naya stat'ya // Konstitutsiya Rossiiskoi Federatsii: Nauchno-prakticheskii kommentarii./ Pod red. akad. B.N. Topornina. M., 1997. S.64.

7. Chirkin V.E. Netipichnye formy pravleniya v sovremennom gosudarstve // Gosudarstvo i pravo. 1994. № 1. S.115.

8. Shakhrai S.M. O Konstitutsii: Osnovnoi zakon kak instrument pravovykh i sotsial'no-politicheskikh preobrazovanii. M., 2013.

9. French R. Parliament, the executive, the courts and the people // Deakin Law Review. 1996. Vol.3. No.1. P.2.

10. Montesk'e Sh. - L. O dukhe zakonov // Montesk'e Sh. - L. Izbrannye proizvedeniya. M., 1955. S.290-291.

11. Barnashov A.M. Teoriya razdeleniya vlastei: stanovlenie, razvitie, primenenie. Tomsk, 1988.

12. Shaio A. Samoogranichenie vlasti (kratkii kurs konstitutsionalizma): Per. s veng. M.: Yurist, 2001. S.83.

13. Dzhefferson T. Avtobiografiya. Zametki o shtate Virginiya. L.: Nauka, 1990. S.196.

14. Dzhefferson T. O demokratii. / Sost. Sol K. Padover. SPb.: Lenizdat, 1992. S.84.

15. Yanov A. Montesk’e protiv Marksa // Obshchestvennye nauki i sovremennost’. 1992. № 1. S.88.

16. Entin L.M. Razdelenie vlastei: opyt sovremennykh gosudarstv. M.: Yurid. lit., 1995.

17. Luzin V.V. Printsip razdeleniya vlastei kak osnova konstitutsionalizma. N.Novgorod, 1997. S.7.

18. Luzin V.V. Poluprezidentskaya model' razdeleniya vlastei (na primere Frantsii) // Pravo i politika. Mezhdunarodnyi nauchnyi zhurnal. 2000. № 1. S.31-40.

19. Korkunov N.M. Russkoe gosudarstvennoe pravo. T.II. Chast' osobennaya. SPb., 1903. S.1-7.

20. Chebotarev G.N. Printsip razdeleniya vlastei v gosudarstvennom ustroistve Rossiiskoi Federatsii. Tyumen', 1997. S.135.

21. Krasnov, M. A. Personalistskii rezhim v Rossii: opyt institutsional'nogo analiza/ M. A. Krasnov. - M.: Fond «Liberal'naya missiya», 2006. - $180 \mathrm{~s}$.

22. Krasnov, M. A. Status glavy gosudarstva kak element avtoritarnogo potentsiala prezidenta / M. A. Krasnov // Gosudarstvo i pravo. - 2015. - № 1. - S. 5-16; № 2. - S. 5-17.

23. Krasnov M.A. Zakonodatel'no zakreplennye polnomochiya Prezidenta Rossii: neobkhodimost' ili servilizm? // Sravnitel'noe konstitutsionnoe obozrenie. 2011. № 4 .

24. Krasnov M.A. Prezident v ekonomike: effekt “kompetentsionnoi gravitatsii”// Obshchestvennye nauki i sovremennost'. 2014. - № 1. S.77-92.

25. A. D. Kerimov, E. V. Khalipova Pravomerno li vydelenie lish' trekh vetvei gosudarstvennoi vlasti? // Politika i Obshchestvo. $-2012 .-3 .-$ C. $42-48$.

26. Arutyunyan G.G. Konsititutsionalizm v kontekste konstitutsionnoi kul'tury novogo tysyacheletiya // Zhurnal zarubezhnogo zakonodatel'stva i sravnitel'nogo pravovedeniya / Journal of foreighn legislation and comparative law. - 2013. - 5. - C. $773-779$.

27. A.V. Bezrukov Rol' Prezidenta Rossii v mekhanizme realizatsii konstitutsionnykh printsipov federalizma, edinstva gosudarstvennoi vlasti i razdeleniya vlastei // Politika i Obshchestvo. - 2013. - 3. - C. 263 - 269. DOI: 10.7256/1812-8696.2013.03.2. 